\title{
Partisipasi Nelayan dalam Kelompok Usaha Bersama Bidang Penangkapan Ikan (Kasus pada KUB di Kecamatan Pangandaran, Kabupaten Pangandaran)
}

\author{
[Fishermen Participation in Collective Business Group of Capture Fisheries; \\ The Case in Pangandaran Subdistrict, District of Pangandaran] \\ Ani Leilani, Ina Restuwati \\ Jurusan Penyuluhan Perikanan - Sekolah Tinggi Perikanan \\ Jalan Cikaret Nomor 2 Bogor, Jawa Barat \\ Diterima: 3 Februari 2016; Disetujui: 27 April 2016
}

\begin{abstract}
Abstrak
Aksi bersama melalui kelompok merupakan strategi bagi nelayan untuk tetap kompetitif dalam lingkungan usahanya. Komitmen dan kontribusi setiap anggota menjadi penting bagi keberhasilan dan kelangsungan kegiatan kelompok yang direfleksikan melalui partisipasi nelayan dalam kelompok. Tujuan penelitian ini adalah: (1) Mengidentifikasi karakteristik nelayan dan karakteristik Kelompok Usaha Bersama (KUB); (2) Mengidentifikasi tingkat partisipasi nelayan dalam KUB; dan (3) Menganalisis hubungan antara tingkat partisipasi nelayan dalam KUB dengan karakteristiknya. Populasi penelitian adalah nelayan di Kecamatan Pangandaran. Jumlah responden penelitian sebanyak 30 orang dari 5 KUB yang diambil secara acak sederhana. Pengumpulan data dilakukan pada Bulan Februari sampai Maret 2015. Data kemudian dianalisis dengan uji korelasi Rank Spearman. Hasil penelitian menunjukkan: (1) Karakterisik nelayan sebagian besar berada pada kategori dewasa (rataan umur 43 tahun) dengan tingkat pendidikan rendah. Skala usaha dan pengalaman nelayan dalam penangkapan ikan berada dalam kategori sedang, dengan tingkat motivasi berkelompok dan tingkat kekosmopolitan sedang. Persepsi nelayan terhadap kelompok sebagian besar berada pada kategori tinggi. Tujuan kelompok, lingkungan interaksi, fungsi kelompok dan perilaku kepemimpinan dinilai baik dan mendukung kegiatan KUB; (2) Partisipasi nelayan dalam KUB tinggi. Derajat keterlibatan nelayan dalam perencanaan, pelaksanaan, evaluasi, dan menikmati hasil KUB sudah berjalan baik; dan (3) Terdapat hubungan signifikan antar partisipasi dan karakteristik pada variabel motivasi berkelompok, tujuan kelompok, lingkungan interaksi kelompok, dan perilaku kepemimpinan.
\end{abstract}

Kata Kunci: karakteristik kelompok, karakteristik nelayan, KUB, partisipasi.

\begin{abstract}
Collective action in group is a strategy for fishermen to remain competitive in a business environment. The commitment and contribution of each member to be important for the success and continuity of the group's activities, both are reflected through the participation of fishermen in the group. The objectives of the study are: (1) To identify characteristics of fishermen and characteristics of the Collective Business Group (KUB); (2) To identify fishermen participation in KUB; and (3) To analyze the relationship between participation of fishermen in KUB and their characteristics. Population of this study are fishermen in Pangandaran Subdistrict. The number of the respondents are 30 fishermen from 5 KUB which were taken by simple random sampling. The data were collected from February-March 2015. The data were analyzed by using Spearman Rank Correlation. The results of the study are: (1) Fishermen characteristics are in adult category (43 years old) with low levels of education. Business scale and experience on capture fisheries are in the medium category, due the level of motivation and cosmopolite levels. Fishermen perception to group mostly in high category. The group's goals, interaction of group, functions and leadership are good and support the activities of KUB; (2) Fishermen participation in KUB were high. The degree of participation in planning, implementation, evaluation, and takes the KUB benefit were high; and (3) There were significant relation between participation, namely: motivation, goals, interaction, and group leadership.
\end{abstract}

Keywords: fishermen characteristics, group characteristics, KUB, participation.

$\triangle$ Penulis korespondensi

Alamat surel: anileilani@yahoo.com 


\section{PENDAHULUAN}

Sektor kelautan dan perikanan di Indonesia diyakini merupakan salah satu sumber utama pertumbuhan ekonomi dengan beberapa alasan, yakni (1) Memiliki kapasitas suplai relatif sangat besar, didukung permintaan yang terus meningkat; (2) Hampir keseluruhan output yang dihasilkan dapat diekspor, dengan input berasal dari sumber daya lokal; (3) Tercatat kegiatan ini mampu membangkitkan industri hulu dan hilir yang besar sehingga dapat menyerap pangsa tenaga kerja yang cukup banyak;

(4) kegiatan ini berlangsung di daerahdaerah; serta (5) Industri perikanan, bioteknologi dan pariwisata bahari memiliki sifat dapat diperbaharui, sehingga mendukung kehadiran secara utuh pembangunan yang berkelanjutan (Anonimus, 2010).

Dalam dunia industri itu sendiri keberadaannya selalu mengalami masa pasang dan surut. Begitu juga dengan agroindustri dan agrobisnis, khususnya industri perikanan yang merupakan penyumbang devisa bagi negara dari sektor non-migas yang cukup besar. Melihat berbagai bukti peningkatan produksi perikanan dari tahun ke tahun, maka untuk tahun ke depannya Indonesia berpotensi mengalami peningkatan lagi atau memiliki prospek yang cerah.
Disamping adanya potensi sumber daya kelautan dan perikanan yang besar, terdapat pula potensi kelembagaan, seperti antara lain peranan Masyarakat Perikanan Nusantara (MPN), Gabungan Pengusaha Perikanan Indonesia yang disingkat Gappindo, Himpunan Nelayan Seluruh Indonesia (HNSI), dan juga LSM Bidang Kelautan dan Perikanan untuk masa-masa yang akan datang terus disinergikan. Potensi lain adalah potensi sarana prasarana yang telah dimiliki, seperti layanan unit karantina ikan, balai pengembangan, balai riset, balai/loka budidaya, sekolah perikanan dan lain-lain (Kementerian Kelautan dan Perikanan, 2009; Anonimus, 2011).

Dengan keberadaan kondisi dan permasalahan yang sedang dihadapi kini, maka diperlukan inovasi dan strategi kebijakan dalam upaya pengelolaan dan pemanfaatan sumber daya kelautan dan perikanan, mengingat Indonesia sebagai negara kepulauan yang seharusnya memiliki wawasan kelautan dalam pembangunan nasional.

Menurut Undang-undang Nomor 16 Tahun 2006 tentang SP3K (Sistem Penyuluhan Pertanian, Perikanan dan Kehutanan) dijelaskan bahwa salah satu bentuk/jenis kelembagaan yang ada di masyarakat adalah kelembagaan pelaku utama yang termuat dalam pasal 19 yang 
menyatakan bahwa, 1). Kelembagaan pelaku utama beranggotakan para petani, para pekebun, para peternak, para nelayan, pembudidaya ikan, pengolah ikan, serta masyarakat di dalam dan di sekitar hutan yang dibentuk oleh pelaku utama baik formal maupun non formal; 2). Kelembagaan mempunyai fungsi sebagai wadah proses pembelajaran, wahana kerja sama, unit penyedia sarana dan prasarana produksi, unit produksi, unit pengolahan dan pemasaran, serta unit jasa penunjang; 3). Kelembagaan dapat berbentuk kelompok, gabungan kelompok, asosiasi, atau korporasi; 4). Kelembagaan yang difasilitasi dan juga diberdayakan oleh Pemerintah dan/atau Pemda agar tumbuh dan berkembang menjadi organisasi yang kuat dan mandiri sehingga mampu mencapai tujuan yang diharapkan para anggotanya.

Salah satu dari sekian banyak kelembagaan yang ada pada masyarakat perikanan adalah kelembagaan pelaku utama yang sebagian besar berada di daerah potensi perikanan seperti Kelompok Usaha Bersama (KUB) dimana anggotanya adalah para nelayan. KUB merupakan salah satu potensi kelembagaan yang lahir dari dan untuk pelaku utama yang berada di lingkungan masyarakat nelayan yang tinggal di sekitar daerah pesisir atau daerah yang berpotensi penangkapan ikan.

Kelompok Usaha Bersama (KUB) Kecamatan Pangandaran merupakan KUB-KUB yang anggota-anggotanya terdiri dari para pelaku utama (nelayan) yang terletak di Desa Pangandaran, Kecamatan Pangandaran dan Kabupaten Pangandaran. KUB yang berada di kecamatan ini terdiri dari beberapa KUB antara lain KUB Kurnia Bahari, KUB Mekar Sari, KUB Mina Bahari, KUB Mina Harapan, KUB Banyuasin, dan KUB Kakap. KUB-KUB ini didirikan dengan tujuan untuk mewadahi kegiatan nelayan di Desa Pangandaran Kecamatan Pangandaran Kabupaten Pangandaran.

Unit produksi KUB yang terdapat di Desa Pangandaran sudah berjalan dengan baik, namun kondisi empiris menunjukkan kelompok bahwa belum menjadi wahana kerjasama sepenuhnya dikarenakan para anggota kelompok waktunya lebih banyak dipergunakan untuk menekuni usaha penangkapannya masing-masing. Hal tersebut dapat dilihat dari sulitnya mengumpulkan para anggota kelompok, kurangnya sumbang saran anggota dalam menyelesaikan permasalahan serta kurangnya informasi tentang penangkapan ikan. Kelompok juga belum menjadi organisasi kegiatan bersama disebabkan karena kurangnya 
koordinasi dan atau informasi dari para pengurus kelompok pada anggotanya sehingga aturan-aturan kelompok belum dapat dijalankan secara optimal.

Sehubungan dengan hal di atas, masalah penelitian (research question) yang ingin dijawab dari penelitian ini adalah: Pertama, bagaimana peran serta (partisipasi) anggota dalam kegiatan kelompok. Peran serta para anggota diidentifikasi dari hal-hal berikut: (1) bagaimana karakteristik dan kemampuan anggota untuk terlibat dalam kegiatan berkelompok?; (2) apa motivasi anggota ikut dalam kegiatan kelompok?; (3) bagaimana sikap dan perilaku yang ditunjukkan anggota dalam kegiatan berkelompok?; Kedua, bagaimana kondisi kelompok usaha bersama (KUB) sebagai faktor pendorong partisipasi. Hal ini dapat diidentifikasi dari: (1) apakah kelompok tumbuh atas dasar kepentingan dan kebutuhan anggota; (2) apakah tujuan kelompok memiliki kesesuaian dengan tujuan anggota; (3) adakah upaya-upaya yang dilakukan dalam memelihara interaksi dalam kelompok; (4) bagaimana perilaku ketua dan juga pengurusnya sebagai unsur kepemimpinan dalam kelompok; dan (5) apakah peran dan fungsi kelompok sudah dapat dijalankan dengan baik.

\section{HASIL DAN PEMBAHASAN}

\section{Karakteristik Individu Nelayan (Pelaku Utama Perikanan)}

Karakteristik nelayan adalah ciriciri atau sifat yang melekat pada diri nelayan sebagai pelaku utama perikanan. Karakteristik nelayan yang diamati dalam penelitian ini adalah umur, tingkat pendidikan formal, tingkat pendidikan non formal, motivasi berkelompok, pengalaman usaha, skala usaha, dan tingkat kekosmopolitan, dengan rataan lamanya menjadi anggota KUB selama lebih kurang tiga tahun. Distribusi responden berdasarkan karakteristik nelayan dalam penelitian ini dijelaskan sebagai berikut :

a. Distribusi Nelayan Berdasarkan Umur.

Umur dalam hal ini, dimaksudkan dalam adalah lama hidup nelayan yang dihitung dalam tahun sejak ia dilahirkan sampai dengan saat penelitian ini dilakukan. Karakter umur dibagi dalam tiga kategori yaitu: muda, sedang dan tua. Kategori muda adalah umur 20 sampai 45 tahun, sedang berkisar 46 sampai 56 tahun, dan kategori tua dengan umur $\geq 57$ tahun.

b. Distribusi Nelayan Berdasarkan Tingkat Pendidikan Formal

Jenjang/tingkat pendidikan yang dimaksudkan dalam penelitian ini adalah tingkat pendidikan formal terakhir 
nelayan yang dapat diselesaikan dengan memperoleh ijazah/tanda tamat hingga dilaksanakannya penelitian ini. Jenjang pendidikan dibagi dalam tiga kategori yakni rendah ialah jenjang SD, kategori sedang jenjang SLTP, dan jenjang SLTA kategori tinggi. Hasil distribusi menghasilkan data dari 30 responden kurang-lebih/sekitar 60 persen nelayan berpendidikan setingkat SD, 33 persen berpendidikan setingkat SLTP dan selebihnya sekitar tujuh persen nelayan berpendidikan setingkat SLTA. Dengan demikian hasil penelitian yang dilakukan mengungkapkan bahwa sebagian besar responden memiliki tingkat pendidikan SD yaitu sebanyak 18 orang.

\section{c. Distribusi Nelayan Berdasarkan Tingkat Pendidikan Non Formal}

Jenjang pendidikan non formal yang dimaksudkan dalam penelitian ini adalah banyaknya nelayan mengikuti pelatihanpelatihan atau pendidikan non formal untuk meningkatkan kemampuan dan keterampilannya dalam hal pengetahuan teknis penangkapan ikan maupun pemasaran, yang dinyatakan dengan frekuensi yang pernah diikuti. Jenjang pendidikan non formal dibagi dalam tiga kategori yakni rendah ialah belum pernah sama sekali pelatihan, sedang pernah mengikuti pelatihan sebanyak 1-2 kali, dan kategori tinggi pernah mengikuti pelatihan $>3$ kali.

Hasil distribusi menghasilkan data dari 30 responden sebanyak 77 persen nelayan belum pernah mengikuti pendidikan pelatihan, 17 persen pernah mengikuti pelatihan 1-2 kali, dan selebihnya 6 persen pernah mengikuti pendidikan pelatihan sebanyak 3 kali. Dengan demikian hasil penelitian mengungkapkan bahwa sebagian besar responden belum pernah mengikuti pendidikan pelatihan yaitu sebanyak 23 orang atau sebesar 77 persen.

\section{d. Distribusi Nelayan Berdasarkan Motivasi Berkelompok}

Distribusi nelayan berdasarkan motivasi berkelompok adalah sampai sejauh mana dorongan dan keinginan dari nelayan responden dalam mengikuti kegiatan kelompok di KUB. Motivasi berkelompok dibagi ke dalam tiga kategori yaitu kategori rendah (skor 915), kategori sedang (skor 16-22) dan kategori tinggi (skor 23-27). Hasil distribusi menghasilkan data dari 30 nelayan responden sebanyak nol persen nelayan yang tercatat mempunyai motivasi berkelompok yang rendah, 54 persen mempunyai motivasi sedang dan sisanya sebesar 46 persen mempunyai motivasi yang tinggi. Dengan demikian hasil penelitian mengungkapkan bahwa 
sebagian besar jumlah nelayan responden memiliki tingkat motivasi berkelompok yang sedang yaitu sebanyak 16 orang.

e. Distribusi Nelayan yang Berdasarkan Pengalaman Usaha

Distribusi nelayan berdasarkan pengalaman usaha adalah berapa lama nelayan responden melakukan usaha penangkapan ikan dan melakukan usaha lain yang dipandang mendukung usaha penangkapan ikan. Pengalaman Usaha nelayan responden dibagi ke dalam tiga kategori yaitu kategori baru ( $<16$ tahun), kategori menengah (17-32 tahun) dan kategori lama ( $\geq 33$ tahun). Hasil distribusi menghasilkan data dari 30 nelayan responden sebanyak 43 persen nelayan mempunyai pengalaman usaha yang rendah, 50 persen mempunyai pengalaman usaha sedang dan sisanya sebesar tujuh persen mempunyai pengalaman usaha yang tinggi. Dengan demikian hasil dari kegitan penelitian mengungkapkan bahwa sebagian besar nelayan responden memiliki pengalaman usaha menengah yaitu sebanyak 15 orang atau sebesar 50 persen.

f. Distribusi Nelayan Berdasarkan Skala Usaha Perikanan Tangkap

Distribusi nelayan berdasarkan skala usaha perikanan adalah berapa widya wisata dan juga bisa bekerjasama dengan kelompok lainnya didalam banyak nelayan responden menggunakan sarana kapal, jenis alat tangkap yang digunakan, jumlah tangkapan per trip serta sistem penangkapan ikan yang dilakukan dalam usaha penangkapan ikan yang dilakukan nelayan. Skala usaha nelayan responden dibagi ke dalam tiga kategori yaitu kategori rendah ( $\leq 1$ unit), kategori sedang (2-3 Unit) dan kategori tinggi ( $\geq 4$ unit). Hasil distribusi menghasilkan data dari 30 responden sebanyak 37 persen nelayan mempunyai skala usaha yang rendah, tercatat 53 persen mempunyai skala usaha sedang dan sisanya sebesar 10 persen mempunyai skala usaha yang tinggi. Dengan demikian hasil kegiatan penelitian ini, yang mengungkapkan bahwa sebagian besar nelayan responden memiliki pengalaman usaha sedang yaitu sebanyak 16 orang atau sebesar 53 persen.

g. Distribusi Pembudidaya Berdasarkan Tingkat Kekosmopolitan

Distribusi nelayan berdasarkan tingkat kekosmopolitan adalah tingkat keterbukaan dan upaya responden untuk selalu berusaha mencari/memperoleh informasi tentang usaha penangkapan terkini, baik yang dilakukannya dengan metoda berkunjung ke luar daerah atau bidang penangkapan, berkonsultasi dengan Penyuluh Perikanan Lapangan 
atau PPL di wilayahnya maupun dengan dinas terkait, melakukan tukar menukar informasi dan pengetahuan dengan sesama nelayan di wilayahnya, serta melakukan akses informasi tentang penangkapan ikan melalui radio, televisi, surat kabar dan media lainnya. Khusus informasi tentang sumber permodalan. Fadel (2009) menjelaskan adanya kucuran modal untuk mendukung usaha ekonomi nelayan. Dengan berbagai infomasi yang dapat diakses nelayan, maka dapat dikatan Tingkat kekosmopolitan nelayan responden dibagi ke dalam 3 kategori yaitu kategori rendah ( $\leq 1$ unit), kategori sedang (2-3 Unit) dan kategori tinggi ( $\geq 4$ unit).

Tabel 1. Rekapitulasi Hubungan hasil kategori karakteristik nelayan dengan partisipasi dalam kelompok KUB

\begin{tabular}{|c|c|c|c|}
\hline \multicolumn{2}{|c|}{$\begin{array}{c}\text { Karakteristik Nelayan } \\
\text { Kategori }\end{array}$} & Frekuensi & $\frac{\text { Persentase }}{(\%)}$ \\
\hline \multirow{3}{*}{$\begin{array}{l}\text { Umur } \\
\text { (rataan umur } 43 \text { tahun) }\end{array}$} & Dewasa muda (20- 45 th) & 17 & 56.67 \\
\hline & Dewasa lanjut (46- $56 \mathrm{tn}$ ) & 11 & 36.67 \\
\hline & Tua ( $\geq 57$ tahun $)$ & 2 & 6.67 \\
\hline \multirow{3}{*}{$\begin{array}{l}\text { Tingkat pendidikan formal } \\
(\text { rataan } S D)\end{array}$} & Rendah (SD) & 18 & 60.00 \\
\hline & Menengah (SLTP) & 10 & 33.00 \\
\hline & Tinggi (SLTA) & 2 & 7.00 \\
\hline \multirow{3}{*}{$\begin{array}{l}\text { Tingkat pendidikan non } \\
\text { formal } \\
(\text { rataan } 0.47 \mathrm{kali})\end{array}$} & Rendah (< 1 kali) & 23 & 76.67 \\
\hline & Sedang (1 - 2 kali) & 5 & 16.67 \\
\hline & Tinggi ( $\geq 3$ kali) & 2 & 6.67 \\
\hline \multirow{3}{*}{$\begin{array}{l}\text { Motivasi berkelompok } \\
\text { (rataan skor 21.83) }\end{array}$} & Rendah (skor 9-15) & 0 & 0.00 \\
\hline & Sedang (skor 16-22) & 16 & 53.33 \\
\hline & Tinggi (skor 23-27) & 14 & 46.67 \\
\hline \multirow{3}{*}{$\begin{array}{l}\text { Pengalaman usaha } \\
\text { (rataan } 17.97 \text { tahun) }\end{array}$} & Baru (<16 tahun) & 13 & 43.33 \\
\hline & Menengah (17-32 th) & 15 & 50.00 \\
\hline & Lama ( $\geq 33$ tahun) & 2 & 6.67 \\
\hline \multirow{3}{*}{$\begin{array}{l}\text { Skala usaha (jumlah kapal) } \\
\text { (rataan } 2 \text { unit) }\end{array}$} & Rendah ( $\leq 1$ unit) & 11 & 36.67 \\
\hline & Sedang (2-3 unit) & 16 & 53.33 \\
\hline & Tinggi ( $\geq 4$ unit) & 3 & 10.00 \\
\hline \multirow{3}{*}{$\begin{array}{l}\text { Tingkat kekosmopolitan } \\
\text { (rataan skor 12.27) }\end{array}$} & Rendah (skor 6-9) & 1 & 3.33 \\
\hline & Sedang (skor 10-13) & 21 & 70.00 \\
\hline & Tinggi (skor 14-18) & 8 & 26.67 \\
\hline
\end{tabular}

Keterangan: $n=30$.

Rataan lama keanggotaan nelayan dalam KUB adalah 3,13 tahun 
Hasil distribusi menghasilkan data dari 30 nelayan responden atau sebanyak tiga persen dari jumlah nelayan tingkat kekosmopolitannya rendah, yang tercatat sekitar 70 persen mempunyai tingkat kekosmopolitan sedang dan sisanya sebesar/senilai 27 persen dengan tingkat kekosmopolitan tinggi. Dengan demikian hasil penelitian mengungkapkan bahwa sebagian nelayan responden memiliki tingkat kekosmopolitan sedang yaitu sebanyak 21 orang atau 70 persen. Disamping itu, menurut Aswanah dkk (2013) untuk mendorong partisipasi nelayan dalam suatu kegiatan program pemerintah, diperlukan ketersediaan dana dari berbagai sumber yang sah; karena pada umumnya kendala terbesar adalah keterbatasan dana.

Tabel 1 di atas menunjukkan bahwa distribusi variabel-variabel karakteristik nelayan setelah melalui proses pengkategorian menghasilkan distribusi yang beragam pada setiap variabelnya. Selanjutnya akan dilakukan proses pengujian dengan memakai uji Rank Spearman untuk mengetahui apakah ada variabel karakteristik nelayan yang sangat signifikan berpengaruh terhadap partisipasinya dalam KUB. Hasil uji tersebut disajikan pada Tabel 2.

Tabel 2. Rekapitulasi Karakteristik Nelayan dan Partisipasinya dalam KUB

\begin{tabular}{|c|c|c|c|c|}
\hline \multirow{2}{*}{$\begin{array}{c}\text { Karakteristik } \\
\text { Nelayan }\end{array}$} & \multicolumn{4}{|c|}{ Partisipasi Nelayan dalam KUB $\left(r_{s}\right)$} \\
\hline & Perencanaan & Pelaksanaan & Evaluasi & $\begin{array}{c}\text { Menikmati } \\
\text { Hasil }\end{array}$ \\
\hline Umur & -.075 & -.206 & -.194 & .014 \\
\hline $\begin{array}{l}\text { Tingkat } \\
\text { pendidikan } \\
\text { formal }\end{array}$ & -.157 & -.179 & -.027 & -.260 \\
\hline $\begin{array}{l}\text { Tingkat } \\
\text { pendidikan non } \\
\text { formal }\end{array}$ & -.072 & -.210 & .158 & -.166 \\
\hline $\begin{array}{l}\text { Motivasi } \\
\text { berkelompok }\end{array}$ & -.159 & $-.449^{*}$ & -.180 & -.241 \\
\hline $\begin{array}{l}\text { Pengalaman } \\
\text { usaha }\end{array}$ & -.021 & .125 & -.194 & .010 \\
\hline Skala usaha & .141 & -.174 & -.014 & -.107 \\
\hline $\begin{array}{l}\text { Tingkat } \\
\text { kekosmopolitan }\end{array}$ & -.148 & .153 & -.131 & .119 \\
\hline
\end{tabular}

Keterangan :

$r_{s} . \quad$ Koefisien korelasi Rank Spearman

*. Correlation is significant at the 0.05 level (2-tailed).

**. Correlation is significant at the 0.01 level (2-tailed). 
Dari Tabel 2 di atas disimpulkan bahwa dari hasil uji Korelasi Rank Spearman menunjukkan karakteristik nelayan yang nampak berhubungan nyata adalah motivasi berkelompok dengan koefesien korelasi Rank Spearman $\left(\mathrm{r}_{\mathrm{s}}\right)$ sebesar -.449 pada taraf kepercayaan $\alpha=0,05$. Terkait dengan suatu status keberlanjutan alat tangkap untuk nelayan kecil, Nababan dkk (2007) mengatakan pentingnya keterpaduan aspek- aspekbio- techno- socioeconomic yang berlaku dalam pengembangan pengelolaan perikanan.

\section{Faktor Kelompok}

Hasil hipotesis dari faktor kelompok dijelaskan bahwa variabel kelompok yang berhubungan dengan partisipasi nelayan dalam KUB adalah lingkungan interaksi kelompok (korelasi sangat signifikan) dan tujuan kelompok (korelasi signifikan), sedangkan variabel lainnya tidak berhubungan. Dengan demikian Hipotesis diterima.

Variabel tujuan dari kelompok berkorelasi sangat signifikan dengan partisipasi nelayan dalam pelaksanaan kegiatan KUB. Variabel antar lingkungan interaksi kelompok berkorelasi sangat signifikan dengan partisipasi nelayan dalam perencanaan dan pelaksanaan kegiatan KUB, serta berkorelasi signifikan dengan partisipasi nelayan dalam evaluasi KUB. Variabel perilaku kepemimpinan ketua kelompok berkorelasi signifikan dengan partisipasi nelayan dalam perencanaan kegiatan KUB. Menurut Arief (2008) pengaruh sistem budaya lokal juga melahirkan cara berpikir dan bertindak yang memandang hubungan manusia dan alam fisik adalah hubungan internal yang bersifat persuasif.

\section{Wujud Partisipasi Nelayan Terhadap Partisipasi dalam KUB}

Dari Tabel 3 di atas disimpulkan bahwa dari hasil uji Korelasi Rank Spearman menunjukkan bahwa variabel faktor kelompok yang sangat signifikan berhubungan dengan partisipasi nelayan dalam KUB adalah variabel lingkungan interaksi kelompok dengan nilai koefesien korelasi Rank Spearman $\left(r_{s}\right)$ sebesar -.546, dan korelasi signifikan pada variabel tujuan kelompok dengan nilai koefesien korelasi Rank Spearman $\left(r_{s}\right)$ sebesar -.383, demikian juga dengan variabel perilaku kepemimpinan ketua kelompok yang berkorelasi signifikan dalam perencanaan kegiatan KUB. 
Tabel 3. Rekapitulasi Hubungan Variabel Faktor Kelompok \& Partisipasinya dalam KUB

\begin{tabular}{|c|c|c|c|c|}
\hline \multirow{2}{*}{$\begin{array}{c}\text { Variabel } \\
\text { Kelompok }\end{array}$} & \multicolumn{4}{|c|}{ Partisipasi Nelayan dalam KUB $\left(r_{s}\right)$} \\
\hline & Perencanaan & Pelaksanaan & Evaluasi & $\begin{array}{c}\text { Menikmati } \\
\text { Hasil }\end{array}$ \\
\hline $\begin{array}{l}\text { Tujuan } \\
\text { Kelompok }\end{array}$ & .348 & $.465^{* *}$ & .177 & .229 \\
\hline $\begin{array}{l}\text { Lingkungan } \\
\text { interaksi } \\
\text { kelompok }\end{array}$ & $.575^{* *}$ & $.569^{* *}$ & $.366^{*}$ & .257 \\
\hline $\begin{array}{l}\text { Fungsi } \\
\text { Kelompok }\end{array}$ & .181 & .342 & .193 & .067 \\
\hline $\begin{array}{l}\text { Perilaku } \\
\text { Kepemimpinan }\end{array}$ & $.393^{*}$ & .111 & .172 & .027 \\
\hline
\end{tabular}

Tabel 4. Hasil Analisis Akhir Hubungan antara faktor kelompok dan partisipasi nelayan

\begin{tabular}{lc}
\hline \multicolumn{1}{c}{ Variabel Kelompok } & $\begin{array}{c}\text { Partisipasi Nelayan dalam } \\
\text { KUB }\left(\mathbf{r}_{\mathbf{s}}\right)\end{array}$ \\
\hline Tujuan Kelompok & $-.383^{* *}$ \\
Lingkungan interaksi Kelompok & $-.546^{* *}$ \\
Fungsi Kelompok & -.297 \\
Perilaku Kepemimpinan & -.207 \\
\hline Kerm
\end{tabular}

Keterangan : $\mathrm{r}_{\mathrm{s}}$. Koefisien korelasi Rank Spearman

*. Correlation is significant at the 0.05 level (2-tailed).

$* *$. Correlation is significant at the 0.01 level (2-tailed).

Analisis akhir disimpulkan bahwa

Faktor kelompok yang berhubungan nyata dengan partisipasi adalah lingkungan interaksi kelompok, tujuan kelompok dan perilaku kepemimpinan kelompok sebagaimana tertuang dalam Tabel 4.

\section{SIMPULAN}

Mayoritas nelayan dalam penelitian ini berumur dewasa muda, tingkat pendidikan rata-rata $\mathrm{SD}$, tingkat pendidikan non formal rendah, memiliki motivasi berkelompok sedang, pengalaman usaha rata-rata menengah, dan skala usaha yang dilakukan sedang. Hasil analisis Rank Spearman pada taraf kepercayaan $\alpha=0,05$ menunjukkan bahwa karakteristik nelayan yang berhubungan nyata dengan partisipasinya dalam Kelompok Usaha Bersama (KUB) adalah motivasi berkelompok yaitu dengan besaran $\left(r_{s}\right)-.449$.

Faktor kelompok yang berhubungan nyata dengan partisipasi adalah lingkungan interaksi kelompok, tujuan kelompok dan perilaku kepemimpinan kelompok. Secara umum terdapat 
hubungan yang cukup erat antara keterlibatan nelayan sebagai anggota dalam Kelompok Usaha Bersama (KUB) terutama partisipasi nelayan dalam merencanakan kegiatan, pelaksanaan maupun evaluasi kelompok. Partisipasi ini tidak terlepas dari perilaku kepemimpinan ketua kelompoknya untuk dapat berkembang terus. Menurut Anonimus (2012), selaku pemimpin pada kelompok terkecil di tingkat komunitas nelayan, diperluhan pemahaman berbagai peraturan yang berlaku.

\section{DAFTAR PUSTAKA}

Anonimus. 2010. Artikel "presiden: lima tahun kedepan peluang dunia usaha" diterbitkan pada tanggal 2 Maret 2010, diakses pada situs http://infobanknews.com.

Anonimus. 2011. Media data riset: surat penawaran "daftar peraturan sektor perikanan Indonesia“ diterbitkan pada bulan Februari 2011.

Anonimus, 2012. Kajian "strategi pengelolaan dan pemanfaatan sumber daya kelautan dan perikanan" oleh Deputi Bidang Sumber Daya Alam dan Lingkungan Hidup Direktorat Kelautan dan Perikanan.

Arief, Andi Adrie. 2008. Partisipasi masyarakat nelayan di Kabupaten Takalar (studi kasus Desa Tamasaju, Kecamatan Galesong Utara). Jurnal Hutan dan Masyarakat Vol III (1): 11-19
Aswanah Yulidin K, Anthon Efani dan Agus Tjahjono. 2013. Evaluasi terhadap implementasi program pengembangan kawasan minapolitan perikanan tangkap di pelabuhan perikanan nusantara (PPN) Brondong Kabupaten Lamongan Jawa Timur. Economic and Social of Fisheries and Marine Journal. Vol 1 (1). 2013

Boston Seminar on Fish. 2007. Data hasil kegiatan pameran perikanan terbesar di dunia, yakni Boston seafood exhibiton show and seminar on fish pada tanggal 11-13 Maret 2007.

Fadel. 2009. Artikel "Fadel minta perbankan kucurkan" diterbitkan pada tanggal 29 Desember 2009, di situs http://bataviase.co.id

Kementerian Kelautan dan Perikanan. 2009. Buku rencana strategis kementerian kelautan dan perikanan tahun 2009-2014.

Nababan B. Osta, Yesi Dewita Sari dan Maman Hermawan. 2007. Analisis keberlanjutan perikanan tangkap skala kecil di Kabupaten Tegal, Jawa Tengah (Tehnik Pendekatan Rapfish). Jurnal Sosial Ekonomi Kelautan dan Perikanan Vol 2 (2) tahun 2007.

Undang-undang RI Nomor 16 tahun 2006. UU No. 16 tahun 2006 tentang SP3K (Sistem Penyuluhan Pertanian, Perikanan dan Kehutanan) 